\title{
Manuscripts as Learning Resources Innovation in Local Content Subjects
}

\author{
$1^{\text {st }}$ Nurhata \\ Prodi Pendidikan Sejarah \\ STKIP Pangeran Dharma Kusuma \\ Jl. KH. Hasyim Asyari, Ds. Segeran \\ Kidul, Kecamatan Juntinyuat, \\ Kabupaten Indramayu \\ elanglangitmendung@gmail.com \\ $4^{\text {th }}$ G E Gemini \\ Prodi Pendidikan Sejarah \\ STKIP Pangeran Dharma Kusuma \\ Jl. KH. Hasyim Asyari, Ds. Segeran \\ Kidul, Kecamatan Juntinyuat, \\ Kabupaten Indramayu \\ $6^{\text {th }} \mathrm{S}$ Ma'mun \\ Prodi Pendidikan Sejarah \\ STKIP Pangeran Dharma Kusuma \\ Jl. KH. Hasyim Asyari, Ds. Segeran \\ Kidul, Kecamatan Juntinyuat, \\ Kabupaten Indramayu
}

\author{
$2^{\text {nd }} \mathrm{W}$ Iryana \\ Prodi Pendidikan Sejarah \\ STKIP Pangeran Dharma Kusuma \\ Jl. KH. Hasyim Asyari, Ds. Segeran \\ Kidul, Kecamatan Juntinyuat, \\ Kabupaten Indramayu \\ $5^{\text {th }} \mathrm{R}$ Tabroni \\ Prodi Pendidikan Sejarah \\ STKIP Pangeran Dharma Kusuma \\ Jl. KH. Hasyim Asyari, Ds. Segeran \\ Kidul, Kecamatan Juntinyuat, \\ Kabupaten Indramayu
}

\author{
$3^{\text {rd }}$ E N Arovah \\ Prodi Pendidikan Sejarah \\ STKIP Pangeran Dharma Kusuma \\ Jl. KH. Hasyim Asyari, Ds. Segeran \\ Kidul, Kecamatan Juntinyuat, \\ Kabupaten Indramayu \\ $6^{\text {th }}$ A A Junaidi \\ Prodi Pendidikan Sejarah \\ STKIP Pangeran Dharma Kusuma \\ Jl. KH. Hasyim Asyari, Ds. Segeran \\ Kidul, Kecamatan Juntinyuat, \\ Kabupaten Indramayu
}

\begin{abstract}
Manuscripts are one important source that can be used as a source of learning in the subject matter (mulok) Indramayu local language (mulok) in elementary and secondary schools in Indramayu. Manuscripts as a mulok learning source can be reached in two ways. First, use the manuscript directly, starting from inventory, description, and editing the manuscript one by one so that the contents of the text contents can be known. The implementation requires synergy with the owner of the manuscript and observers of the manuscript. Second, an inventory of the results of previous studies of Indramayu manuscripts. In this second method, both mulok teachers and mulok book compilers can directly utilize previous research on Indramayu manuscripts. The use of manuscripts or research results on Indramayu manuscripts will provide innovation for the learning of Indramayu Language.
\end{abstract}

Keywords-manuscript, mulok (muatan lokal), Indramayu

\section{INTRODUCTION}

Local content subjects (mulok) in Indramayu are in the form of Indramayu Language. Mulok Indramayu Language is taught at elementary and secondary school levels. According to Primary and Secondary Education Data, the number of schools in Indramayu Regency is 898 Elementary Schools, 216 Junior High Schools, 55 High Schools, and 138 Vocational High Schools (1).

The material of mulok Indramayu Language includes Indramayu language and literature and Javanese script. Other types of mulok, such as Environmental Education
(Pendidikan Lingkungan Hidup), Sundanese, Characteristics (budi pekerti), Theater, and Mangrove Schools, only a few schools apply it. One of the main factors is that not all mulok teachers master the Indramayu language, Indramayu literature or Javanese script.

Exploration of Indramayu's language and literature, including Javanese script, cannot be separated from manuscripts, which are the main objects of philological research. The Indramayu Manuscripts, written mostly in Javanese script, contain old language and literature.

Philology can also be interpreted as knowledge of literature in a broad sense, which includes the fields of language, literature, and culture (2). There are two elements in the manuscript, namely physical (concrete) and textual (abstract) elements. The study of all physical aspects of manuscripts is called codicology, such as studying manuscript material, the age of the manuscript, where the manuscript is written, estimates of manuscript writing, and others. Meanwhile, the study of the content of texts is called textology, such as studying the decline of texts, interpretation of texts, and understanding texts (2).

The term manuscript, by the people of Indramayu, is called lontar, although the writing pad used is not made from palm leaves (palm). To track how many manuscripts scattered in the Indramayu community can see the Katalog Naskah Indramayu, totaling 92 manuscripts. Previous studies, recorded 124 manuscripts, as described in "Kearifan Lokal dalam Naskah-naskah Pesisir 
Indramayu: Pemanfaatan Tacit Knowledge untuk pengembangan budaya pesisir melalui Knowledge Management System (KMS)". There are still many manuscripts that have not been recorded, stored in the houses of villagers. If accumulated, there will be more. The abundance of Indramayu manuscripts is related to the long history of Indramayu, which according to some traditional historiographies has taken place since the 15 th century (2)(3).

However, the Indramayu Language language has not yet optimized the manuscripts. The importance of using manuscripts as a source of mulok learning because in it there is a picture of the nature of the mind or feelings, customs, beliefs, and value systems of society in the past (4)(2). The causal factor is that the manuscripts are not easy to access. Indramayu Regional Archive and Library Office, up to now has not yet taken any concrete steps, such as inventory of manuscripts, digitalization of manuscripts, or acquisition of manuscripts. Besides, the characters and languages of the manuscript are not easy to understand.

Research on the use of manuscripts as teaching material in Indonesian Indramayu language has not been conducted. The related research is explained in the paper "Implementasi Pembelajaran Bahasa Daerah sebagai Muatan Lokal", about the significance of regional languages for mulok learning. This research confirms that regional languages can be used as mulok subjects (5). However, this research does not mention the significance of language in manuscripts for teaching local languages, only emphasizing oral sources.

Therefore, research on manuscript-based mulok learning Indramayu is urgent. The goal is that the potentials and advantages of the region as well as the regional cultural treasures contained in the manuscript can be introduced to students. In turn, this can foster local awareness and local culture of students. This is a form of support for the Kurikulum Nasional (Kurtilas) through mapel mulok the Indramayu Language (6).

\section{A. Legal Basis}

\section{ANALYSIS AND DISCUSSION}

The development of mulok subjects in the education unit in Indramayu is related to the West Java Provincial government policy series. In 1994, mulok in Indramayu included Sundanese and Indramayu (Javanese dialect Indramayu), based on the Decree of the Head of the Regional Office of the Ministry of Education and Culture, West Java Province No. 849/102 / Kep / A / 1994 (7). In 1996 , the policy was changed, which states that in West Java there is only Sundanese because most West Javanese speakers speak Sundanese. This was stated in the Regional Regulation (Perda) of West Java Province No. 6 of 1996 concerning Preservation, Development, and Development of Sundanese Language, Literature, and Literacy (8).

The 1996 Regional Regulation was amended in 2003 which stated that there were three local languages (mother tongue) in West Java, namely Sundanese, Betawi Malay, and Cirebon (Cirebon dialect of Javanese). The legal basis is Perda No. 5 of 2003 concerning the Preservation,
Development, and Development of Regional Languages, Literature, and Literacy in West Java (9). In this context, mulok Indramayu Language becomes part of the Cirebon Language mulok. Then exit Regulation No. 14 of 2014, as a revision of Perda No. 5 of 2003 concerning the Maintenance, Development, and Development of Languages, Literature, and Local Literacy in West Java (10). This regulation is more open, which implicitly provides opportunities for each region to raise the cultural potential or the surrounding social environment. Based on that, the Regional Government of Indramayu Regency reestablished the Indramayu Language as mulok material.

Determination of Indramayu Language as mulok material is in line with West Java Governor Regulation No. 69 of 2013 concerning Learning the Local Content of Regional Languages at the Level of Primary and Secondary Education (11); Letter of the Head of West Java Province Education Office No. 423.5 / 60-Set-Disdik dated 5 January 2015 concerning the Use of the Mulok Language and Regional Literature Curriculum (12); Letter of the Head of West Java Province Education Office No. 423/2372 / Set-Disdik dated 26 March 2013 concerning Regional Language Subjects (13).

The orientation of the learning of the Indramayu Language is that of introducing the Indramayu language, Indramayu literature, as well as the Javanese script (the script that was used by the Indramayu people), to the students. However, it is not yet linked to the manuscript, a relic of abundant cultural heritage. The presence of manuscripts as one of the sources of the Indramayu language will have an impact on the innovation of the Indramayu Language because in it there is knowledge and local wisdom in the past that might still be relevant to be reintroduced to millennials.

\section{B. The manuscript as a learning resource}

Manuscripts can be used as learning resources, as the ancestors did. Learning resources are related to efforts to enrich the learning experience. Learning resources are needed to support the learning process so that the objectives of learning can be achieved. With the source of learning, the transformation of knowledge can run effectively and students have the competence (14). This opinion is in line with the Association for Educational Communications and Technology (AECT) and Banks (15) which states that learning resources are useful for the interests of learning, to increase effectiveness and efficiency.

There are two types of learning resources, namely learning resources that are deliberately arranged for learning (learning resources by design) and learning resources that are available but can be used for learning (learning resources by utilization) (16). The results of previous studies on Indramayu manuscripts are included in the first type of learning resources, while the manuscripts themselves (which are still scattered in the Indramayu community) are among the second types of learning resources.

On this occasion, what we will describe is the significance of the Indramayu manuscripts and the results of research on the Indramayu manuscripts for the learning 
of the Indramayu language, which includes Indramayu language, Indramayu literature, and Javanese script.

C. Indramayu Language

The term Indramayu language refers to the Javanese understanding of the Indramayu dialect. Research on Javanese Indramayu dialect was first described by $\mathrm{J}$. Groneman in 1893, in Javaansch dialekt van Dermajoe (Indramajoe). The book discusses several different terms between Javanese in the center of Javanese culture (ora, enthék, irung) and Javanese that are used by the Indramayu people (beli, enthong, cungur). The explanation is written using Javanese script (17). If you look at the vocabulary list in the book, it seems that the research data use oral sources.

In the oral variety, there are two languages used by the Indramayu community, namely Javanese Indramayu dialect and Sundanese Indramayu dialect. In the Javanese dialect, Indramayu has many similarities with the Javanese Cirebon dialect. That is why, in 2003, Javanese Indramayu dialect was considered similar to Javanese Cirebon dialect. The number of Sundanese speakers in the Indramayu dialect is very small, only in certain regions, including Parean and Haurgeulis.

If you look at the manuscripts found in Indramayu, most of the manuscripts are written in Javanese, using Javanese script and Pegon script. The number of Javanese manuscripts written in Latin is very small. Besides, there are several Arabic manuscripts written in Arabic script, Javanese script, and Latin script. Meanwhile, Sundaneselanguage manuscripts or manuscripts written with Sundanese characters have not yet been found.

By paying attention to the manuscript it will show the treasures of the language used or known by the Indramayu community in the past few centuries. Of course, it can complement the learning of Indramayu's mulok Language which is more uplifting oral language (oral tradition). For example, in the source of the manuscript, the equivalent of the word "talk", namely clatu, ngandika, mojar, gunem, tembung, wacana, ucap, kanda, ujar, cariyos, sabda, andothers. The wealth of diction was not yet explored for the learning of Indramayu Language mulok. The textbooks available also appear to be more viscous as an Indonesian translation into the Indramayu language (the oral variety used by the Indramayu community today) in which the structure of the language follows the Indonesian EYD.

To collect old vocabulary in manuscripts, you can use previous research, in the form of text edits. So, do not have to be in direct contact with the manuscript. Through the edits of the text, it will be seen how many variants of the Javanese dialect of Indramayu, how they are used in verbal or non-verbal communication, and so on. Revitalizing the old vocabulary for mulok learning is the mandate of the Regional Regulation, regarding the maintenance, guidance and development of regional languages, as described above.

D. Indramayu Literature

Broadly speaking, Indramayu's literature is a part of Nusantara's literature, through the tradition of copying manuscripts and oral traditions which are very long, which in their development are adapted to the local culture. Between the written tradition (manuscript) and the oral tradition (oral literature), the two cannot be separated. In the past, when someone wrote or copied text in the form of the song (macapat) while it was sung loudly with Javanese meter. On certain occasions, the tembang form text was also read in front of many people.

There are several Indramayu literature that is quite popular to this day, such as the story of Ki Gede Junti's daughter who was proposed by Dampu Awang (Ma Huan), the interpreter of Admiral Cheng Ho. The written source of the story is described in the Nyi Junti manuscript in the form of a macapat song. In the context of traditional historiography, the figure of Dampu Awang is not only connected with great figures (gegedén) in Indramayu and Cirebon but also connected with the myths of the kings in Southeast Asia. In Bali Dampu Awang is known as Ki Mpu Awang; in Madura it is known as Dempo Abang or Sampo Tua Lang; in Banjarmasin, it is known as Dampu Awang or Sampukong. Some chronicles that tell about it include Hikayat Raji Akil, Babad Blambangan, Babad Blambangan, Hikayat Raja-raja Pasai, Hikayat Hang Tuah, and Hikayat Banjar (18).

In addition to the stories of Nyi Junti and Ki Dampu Awang, stories of Cirebon origins (Cirebon Babad manuscripts) and Indramayu origins stories (Babad Darmayu manuscripts) are also quite popular among the Indramayu people. The number of copies of manuscripts is quite abundant, reaching tens. It shows that both stories are very popular with the community.

However, not a bit of old literature that was once popular through copying traditions (manuscripts), is now almost unknown to the Indramayu community, such as Hikayat Siti Hasanah, Ken Arok Ken Dedes, Jaran Sari Jaran Purnama, Patih Suba, Syekh Jatiswara, Dewi Ratna Ayu, Syekh Madekur, Sedjarah Kuntjit, Menak Kambyah, and Dewi Ratna Ayu, and others. This old literary treasure will provide its color for the learning of regional literature through the language Indramayu.

In addition to the old literary genre of history, in Indramayu, there are also various literary genres of the book, such as tarekat, remembrance, prayer, interpretation, al-Quran, recitation, reconciliation of Islam, usululuddin, fiqh, Sufi science, ratib, amulets, treatises, wills, and the book of medicines (19). Through such book literature, illustrated how religious traditions (Islam) and science developed in Indramayu some time ago. However, the literature of this book is rarely introduced to students through the language Indramayu.

The old Indramayu literature above can be a reference for Indramayu literary material, which has so far emphasized oral literature. That the learning of Indramayu literature describes more oral literature is seen in Blajar Basa lan Sastra Cerbon-Dermayu kanggé Murid SD/MI Kelas VI (20). In the textbook, discussions about Indramayu's literature (also Cirebon) include parikan, tarling song, story prose, paribasa, modern song, wangsalan (pantun), badékan (guessing). Likewise in Budaya Dermayu: Nilai-nilai Historis, Estetis, dan Transendental (21), most of them present oral literature, 
such as parikan, wangsalan, perlambang, sandisastra, sasmita, panyandra, sanepa, ukara sesumbar, basa prenesan, basa rinengga, gugon tuwon, kakawin, and kidung. The literature described in the two books is largely not written in the manuscript.

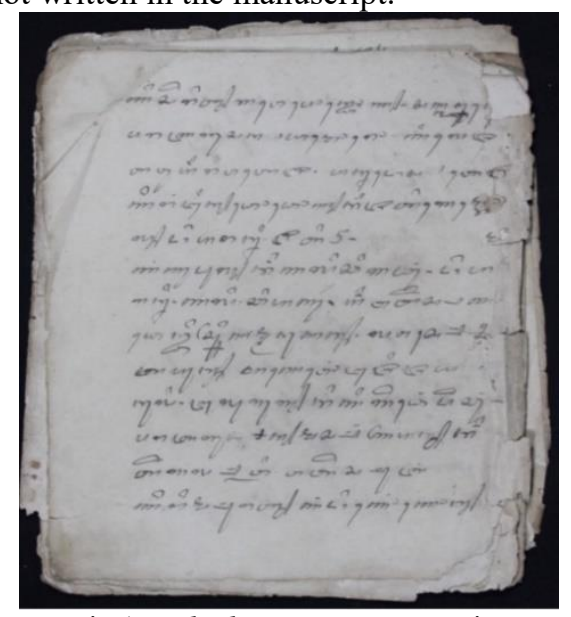

Fig.1. Babad Darmayu manuscript

By utilizing manuscripts as one of the sources for teaching Indramayu Language, through Indramayu literary material, it can be seen from the old literature of the Indramayu people and the names of the old poets who produced it. Some of the names of Indramayu's old poets include Jaka Sari (born 1870, writer of the Sedjarah Kuntjit manuscript in 1918), Sugrawijaya (author of the KitabKidungan manuscript, 1927), Dulpari (writer of the Cirebon Babad manuscript, around 1862), Jeminah (writer of the Primbon Pétungan manuscript), Sarman (writer of the KitabKejawén manuscript, 1934), and others.

How to use Indramayu's old literature can see the results of previous studies based on the Indramayu manuscript, in the form of text edits and translations. Some institutions that save the results of research on the edits of the Indramayu manuscripts include the Sri Baduga Museum in Bandung, the National Library of the Republic of Indonesia (PNRI), the Indramayu Regional Library, and the University of Indonesia Library (UI).

E. Javanese script

Manuscripts found in Indramayu were written using Javanese, Arabic, Pegon, and Latin scripts. In Javanese script, now few people can read and write it because these ancient scripts are no longer practiced in people's daily activities. Meanwhile, in Arabic and Pegon scripts, they are still taught and practiced in Islamic boarding schools and madrasa schools (semi-formal education). For Latin characters, it is still at a safe level, because until now it is still used.

Of the four scripts, which are in line with theKurikulum Bahasa Indramayu atau mulok Bahasa Indramayu, namely Javanese script. Moreover, in Indramayu, Javanese-language manuscripts are the most numerous. Of 92 manuscripts 86 (112 texts) of them were written in Javanese script. In general, the age of Javanesewritten manuscripts is older (22). This fact also confirms that long before the Indramayu people knew Latin script,
Javanese script was used in a mass time to write various kinds of texts or literature.

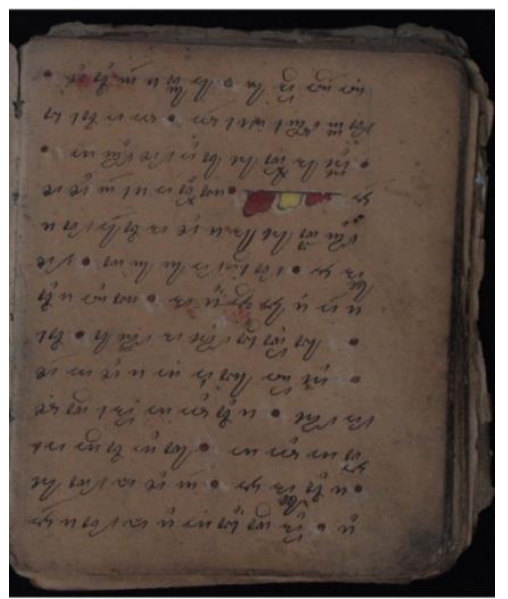

Fig.2. Jaran Sari Jaran Purnama manuscript, Javanese script

So it is not excessive if the Javanese script becomes a door for someone when they want to enter the realm of thought, local wisdom, or the customs of the Indramayu community in particular or Javanese society in general in the past. Even though Javanese manuscripts have diverse characters, which are different from conventional (Javanese) print texts. Of course, this is a challenge for its readers.

This manuscript-based Javanese script learning confirms the teachers and students about the benefits of learning to read and write Javanese scripts in the language Indramayu. Which one of the benefits can be a tool to explore local knowledge and wisdom contained in the manuscript. In this context, synergy is needed between mulok instructors and observers of manuscripts or owners of manuscripts (more than 15 owners of manuscripts) so that the manuscripts scattered in the Indramayu community are useful for the development of the Indramayu Language mulok.

\section{CONCLUSION}

In Indramayu, mulok material at primary and secondary school levels is generally in the form of Indramayu Language. Mulok Indramayu Language in it includes Indramayu language and literature and Javanese script. Mulok Bahasa Indramayu requires a lot of innovation to raise more excellence and cultural potential of the region. One of them, by utilizing Indramayu manuscripts and research results (text edits) based on Indramayu manuscripts. Through this manuscript, Indramayu's language and literary wealth will be seen to have developed some time ago, which can be used as capital for the learning of Indramayu's mulok learning.

\section{REFERENCES}

[1] Data Pokok Pendidikan Dasar dan Menengah Direktorat Jenderal Pendidikan Anak Usia Dini, Pendidikan Dasar dan Pendidikan Menengah Kementerian Pendidiian dan Kebudayaan [Internet]. 2020. Available from: https://dapo.dikdasmen.kemdikbud.go.id/sp/2/021800

[2] Baried SB. Pengantar Teori Filologi. Yogyakarta: Badan Penelitian dan Publikasi Fakultas (BPPF) Seksi Filologi Fakultas Sastra Universitas Gajah Mada; 1985.

[3] Christomy T, Nurhata. Kearifan Lokal dalam Naskah-Naskah Pesisir Indramayu: Pemanfaatan Tacit Knowledge untuk 
pengembangan budaya pesisir melalui Knowledge Management System (KMS). In DRPM UI; 2013.

[4] Ikram A. Filologi Nusantara. Jakarta: Pustaka Jaya; 1997

[5] Wibawa S. Implementasi Pembelajaran Bahasa Daerah sebagai Muatan Lokal. In 2007.

[6] Basari A. Penguatan Kurikulum Muatan Lokal dalam Pembelajaran di Sekolah Dasar. In 2014.

[7] Keputusan Kepala Kantor Wilayah Departemen Pendidikan dan Kebudayaan Provinsi Jawa Barat No. 849/102/Kep/A/1994. 1994.

[8] Peraturan Daerah (Perda) Provinsi Jawa Barat No. 6 Tahun 1996 tentang Pemeliharaan, Pembinaan, dan Pengembangan Bahasa, Sastra, dan Aksara Sunda. 1996.

[9] Peraturan Daerah (Perda) No. 5 Tahun 2003 Tentang Pemeliharaan, Pembinaan, dan Pengembangan Bahasa, Sastra, dan Aksara Daerah di Jawa Barat. 2003.

[10] Perda No.14 Tahun 2014 tentang Pemeliharaan, Pembinaan, dan Pengembangan Bahasa, Sastra, dan Aksara Daerah di Jawa Barat. 2014

[11] Peraturan Gubernur (Pergub) Jawa Barat No. 69 Tahun 2013 tentang Pembelajaran Muatan Lokal Bahasa dan Sastra Daerah pada Jenjang Satuan Pendidikan Dasar dan Menengah. 2013.

[12] Surat Kepala Dinas Pendidikan Provinsi Jawa Barat Nomor 423.5/60-Set-Disdik tanggal 5 Januari 2015 tentang Penggunaan Kurikulum Mulok Bahasa dan Sastra Daerah. 2015.
[13] Surat Kepala Dinas Pendidikan Provinsi Jawa Barat No. 423/2372/Set-Disdik tanggal 26 Maret 2013 tentang Mata Pelajaran Bahasa Daerah. 2013.

[14] Suyanto, Djihad A. Calon Guru dan Guru Profesional. Yogyakarta: Multi Pressindo; 2012.

[15] Komalasari K. Pembelajaran Kontekstual: Konsep dan Aplikasi. Bandung: PT. Refika Aditama; 2014.

[16] Tasri L. Pengembangan Bahan Ajar Berbasis Web. J Meditek. 2011;3(2):1-8.

[17] Groneman J. Javaansch dialekt van Dermajoe (Indramajoe). Batavia: Albrecht en Rusche; 1893.

[18] Manguin P-Y. The Merchant and the King: Political Myths of Southeast Asian Coastal Polities. Indonesia. 1991;52:41-54.

[19] Liaw YF. Sejarah Kesusastraan Melayu Klasik, Jilid II. Jakarta: Erlangga; 2011.

[20] Kasim S. Blajar Basa lan Sastra Cerbon-Dermayu kanggé Murid SD/MI Kelas VI. Bandung: Dinas Pendidikan Provinsi Jawa Barat; 2015.

[21] Kasim S. Budaya Dermayu: Nilai-nilai Historis, Estetis, dan Transendental. Yogyakarta: Gapura; 2012.

[22] Christmoy T, Nurhata. Katalog Naskah Indramayu. Jakarta: WWS; 2016. 